\title{
Travel-associated chikungunya acquired in Myanmar in 2019
}

Marta Díaz-Menéndez ${ }^{1,2}$, Elena Trigo Esteban ${ }^{1,2}$, Mugen Ujiie3, Guido Calleri4, Camilla Rothe ${ }^{5}$, Denis Malvy ${ }^{6}$, Emanuele Nicastri7, Alfred L Bissinger ${ }^{8}$, Marc Grandadam 9 , Jonathan D Alpern ${ }^{10}$, Federico Gobbi ${ }^{11}$, Patricia Schlagenhauf ${ }^{12}$, Alexandre Duvignaud ${ }^{13}$,

Emilie Javelle ${ }^{14}$, Takato Nakamoto ${ }^{15}$, Spinello Antinori ${ }^{16}$, Davidson H Hamer ${ }^{17}$

1. National Referral Unit for Imported Tropical Diseases. Department of Internal Medicine. Hospital Universitario La Paz-Carlos III, IdiPAZ, Madrid, Spain

2. These authors contributed equally to the work

3. Vaccination Support Center, Disease Control and Prevention Center. National Center for Global Health and Medicine, Tokyo, Japan

4. Travel Medicine Unit. Amedeo di Savoia Hospital. ASL Città di Torino, Torino, Italy

5. LMU Hospital Centre, Division of Infectious Diseases and Tropical Medicine, Munich, Germany

6. Department of Infectious Diseases and Tropical Medicine, CHU de Bordeaux \& INSERM 1219, University of Bordeaux, Bordeaux, France

7. National Institute for Infectious Diseases Lazzaro Spallanzani, IRCCS, Rome, Italy

8. Institute for Tropical Medicine, Department of Internal Medicine, University Hospital Tübingen, Germany

9. Arbovirus \& Emerging viral diseases laboratory. Institut Pasteur du Laos, Vientiane, Laos

10. Department of Travel and Tropical Medicine, HealthPartners; Department of Medicine, University of Minnesota, Minneapolis, United States

11. Department of Infectious / Tropical Diseases and Microbiology, IRCCS Sacro Cuore Don Calabria Hospital, Negrar, Verona, Italy

12. University of Zürich Centre for Travel Medicine, WHO Collaborating Centre for Travellers' Health, Zürich, Switzerland

13. Department of Infectious Diseases and Tropical Medicine, CHU de Bordeaux \& INSERM 1219, University of Bordeaux, Bordeaux, France

14. Laveran Military Teaching Hospital, Aix Marseille Univ, IRD, AP-HM, SSA, VITROME, Marseille, France

15. Disease Control and Prevention Center, National Center for Global health and Medicine, Tokyo, Japan

16. Department of Biomedical and Clinical Sciences "L Sacco", University of Milan. Tropical Medicine Unit, ASST Fatebenefratelli Sacco, Milan, Italy

17. Department of Global Health and Boston University School of Public Health and Section of Infectious Diseases, Department of Medicine, Boston University School of Medicine, Boston, MA, United States

Correspondence: Marta Díaz-Menéndez (marta.diazmenendez@gmail.com)

Citation style for this article:

Díaz-Menéndez Marta, Esteban Elena Trigo, Ujiie Mugen, Calleri Guido, Rothe Camilla, Malvy Denis, Nicastri Emanuele, Bissinger Alfred L, Grandadam Marc, Alpern Jonathan D, Gobbi Federico, Schlagenhauf Patricia, Duvignaud Alexandre, Javelle Emilie, Nakamoto Takato, Antinori Spinello, Hamer Davidson H. Travel-associated chikungunya acquired in Myanmar in 2019. Euro Surveill. 2020;25(1):pii=1900721. https://doi.org/10.2807/1560-7917.ES.2020.25.1.1900721

Article submitted on 24 Nov 2019 / accepted on 09 Jan 2020 / published on 09 Jan 2020

Eighteen cases of chikungunya virus infection in travellers returning from Myanmar were reported to the GeoSentinel Surveillance Network, its subnetwork EuroTravNet and TropNet in 2019, reflecting an ongoing local outbreak. This report reinforces the importance of travellers as sentinels of emerging arboviral outbreaks and highlights the importance of vigilance for imported cases, due to the potential for dissemination of the virus into areas with competent local vectors and conducive environmental conditions.

In early October 2019, a GeoSentinel Surveillance Network site in Madrid, Spain, identified two patients with chikungunya virus (CHIKV) infection who had recently visited Myanmar. Rapid outreach to GeoSentinel sites (including EuroTravNet), TropNet and Laos external collaborators identified 16 additional infected travellers who acquired CHIKV infection in Myanmar during 2019.

According to a newspaper report, the Myanmar Department of Public Health identified an outbreak of
CHIKV infection in 2019, mainly in Nay Pyi Taw, Kachin State, and Tanintharyi Region, Myanmar [1]. In the previous 8 years however, no cases of CHIKV infection had been officially reported in the country $[2,3]$.

We describe travellers with imported CHIKV infection from Myanmar who were diagnosed in 2019 (January to November) and identified at GeoSentinel, EuroTravNet and TropNet sites. Some epidemiological and clinical information as well as places visited by the travellers are presented.

\section{Case finding}

GeoSentinel is a global surveillance network for emerging infectious diseases that has 68 sites in 28 countries; EuroTravNet is its European subnetwork; TropNet represents a separate European surveillance entity represented by 75 specialised tropical medicine centres in Europe.

For chikungunya surveillance, GeoSentinel follows case definitions proposed by the World Health Organization 


\section{TABLE 1}

Epidemiological and travel characteristics of confirmed and probable chikungunya cases among travellers returning from Myanmar, $2019(\mathrm{n}=18)$

\begin{tabular}{|c|c|c|c|c|c|c|c|}
\hline Case & $\begin{array}{l}\text { Reporting } \\
\text { country }\end{array}$ & Places visited in Myanmar & $\begin{array}{l}\text { Pre-travel } \\
\text { consultation }\end{array}$ & $\begin{array}{l}\text { Period of stay in } \\
\text { Myanmar } \\
\text { (length of } \\
\text { exposure period) }\end{array}$ & $\begin{array}{l}\text { Approximate } \\
\text { age in years }\end{array}$ & $\begin{array}{l}\text { Underlying medical } \\
\text { condition(s) }\end{array}$ & $\begin{array}{l}\text { Month of } \\
\text { symptom } \\
\text { onset }\end{array}$ \\
\hline 1 & Japan & Yangon & Yes & $\begin{array}{c}\text { Apr } 2017 \text { to Jul } \\
2019 \\
\text { (NA) }\end{array}$ & 60 & Hypertension & Jul 2019 \\
\hline 2 & Japan & Yangon, Naypyidaw & No & $\begin{array}{l}\text { Aug } 2019 \\
\text { (6 days) }\end{array}$ & 25 & Atopic dermatitis & Aug 2019 \\
\hline 3 & France & Shan state, Bagan, Yangon & Yes & $\begin{array}{l}\text { Jul } 2019 \\
\text { (12 days) }\end{array}$ & 45 & No & Aug 2019 \\
\hline 4 & Italy & Nyaungshwe & Yes & $\begin{array}{c}\text { Lived in Myamnar } \\
\text { until Aug } 2019 \\
\text { (NA) }\end{array}$ & 60 & No & Aug 2019 \\
\hline 5 & Japan & Yangon & Yes & $\begin{array}{c}\text { Aug } 2018 \text { to Aug } \\
2019 \\
\text { (NA) }\end{array}$ & 70 & $\begin{array}{l}\text { Hyperlipidaemia, } \\
\text { hypertension, } \\
\text { diabetes mellitus }\end{array}$ & Aug 2019 \\
\hline 6 & France & $\begin{array}{c}\text { Yangon, Hpa-An, Moulmein, } \\
\text { Ye, Mandalay, Bagan, Inle } \\
\text { lake, Pindaya }\end{array}$ & Yes & $\begin{array}{c}\text { Jul to Aug } 2019 \\
\text { (23 days) }\end{array}$ & 45 & No & Aug 2019 \\
\hline 7 & $\begin{array}{l}\text { United } \\
\text { States }\end{array}$ & Ye, (Mon State), Yangon & Unknown & $\begin{array}{l}\text { May to Aug } 2019 \\
\text { (65 days) }\end{array}$ & 20 & No & Jul 2019 \\
\hline 8 & Spain & Yangon, Mandalay, Inle Lake & No & $\begin{array}{l}\text { Aug } 2019 \\
\text { (7 days) }\end{array}$ & 30 & No & Aug 2019 \\
\hline 9 & Spain & $\begin{array}{c}\text { Yangon Mandalay, Inle Lake, } \\
\text { Bagan }\end{array}$ & No & $\begin{array}{l}\text { Aug } 2019 \\
\text { (14 days) }\end{array}$ & 55 & No & Aug 2019 \\
\hline 10 & Italy & $\begin{array}{l}\text { Yangon, Mandalay, Inle } \\
\text { Lake, }\end{array}$ & No & $\begin{array}{c}\text { Aug to Sep } 2019 \\
\text { (12 days) }\end{array}$ & 50 & No & Sep 2019 \\
\hline 11 & Italy & Yangon, Mandalay, Inle Lake & No & $\begin{array}{l}\text { Aug to Sep } 2019 \\
\text { (12 days) }\end{array}$ & 50 & No & Sep 2019 \\
\hline 12 & Laos & Mandalay & No & $\begin{array}{l}\text { Sep } 2019 \\
\text { (12 days) }\end{array}$ & 50 & No & Sep 2019 \\
\hline 13 & Germany & $\begin{array}{c}\text { Yangon, Inle Lake, Bagan, } \\
\text { Mandalay }\end{array}$ & Yes & $\begin{array}{l}\text { Jan } 2019 \\
\text { (15 days) } \\
\end{array}$ & 65 & Mitral valve disease & Feb 2019 \\
\hline 14 & Germany & $\begin{array}{c}\text { Yangon, Inle Lake, Bagan, } \\
\text { Mandalay }\end{array}$ & Yes & $\begin{array}{l}\text { Jan } 2019 \\
\text { (15 days) } \\
\end{array}$ & 30 & No & Feb 2019 \\
\hline 15 & Italy & Yangon, Bagan, Mandalay & No & $\begin{array}{l}\text { Jul to Aug } 2019 \\
\text { (12 days) }\end{array}$ & 65 & Hypertension & Jul 2019 \\
\hline 16 & Italy & Rangoon, Bagan & No & $\begin{array}{l}\text { Aug } 2019 \\
\text { (10 days) }\end{array}$ & 55 & No & Aug 2019 \\
\hline 17 & Germany & $\begin{array}{c}\text { Yangon, Inle Lake, } \\
\text { Mandalay, Bagan, Thandwe/ } \\
\text { West Coast }\end{array}$ & No & $\begin{array}{l}\text { Oct } 2019 \\
\text { (16 days) }\end{array}$ & 25 & No & Oct 2019 \\
\hline 18 & France & $\begin{array}{l}\text { Yangon, Mandalay, Bagan, } \\
\text { Inle Lake }\end{array}$ & Unknown & $\begin{array}{l}\text { Oct to Nov } 2019 \\
\text { (15 days) }\end{array}$ & 55 & No & Oct 2019 \\
\hline
\end{tabular}

F: female; Ig: immunoglobulin; M: male; NA: not assessed; VFR:visiting friends and relatives.

age rounded by five. 


\section{FIGURE}

Possible places of exposure: destinations visited by travellers before chikungunya virus infection, Myanmar, $2019(\mathrm{n}=18)$

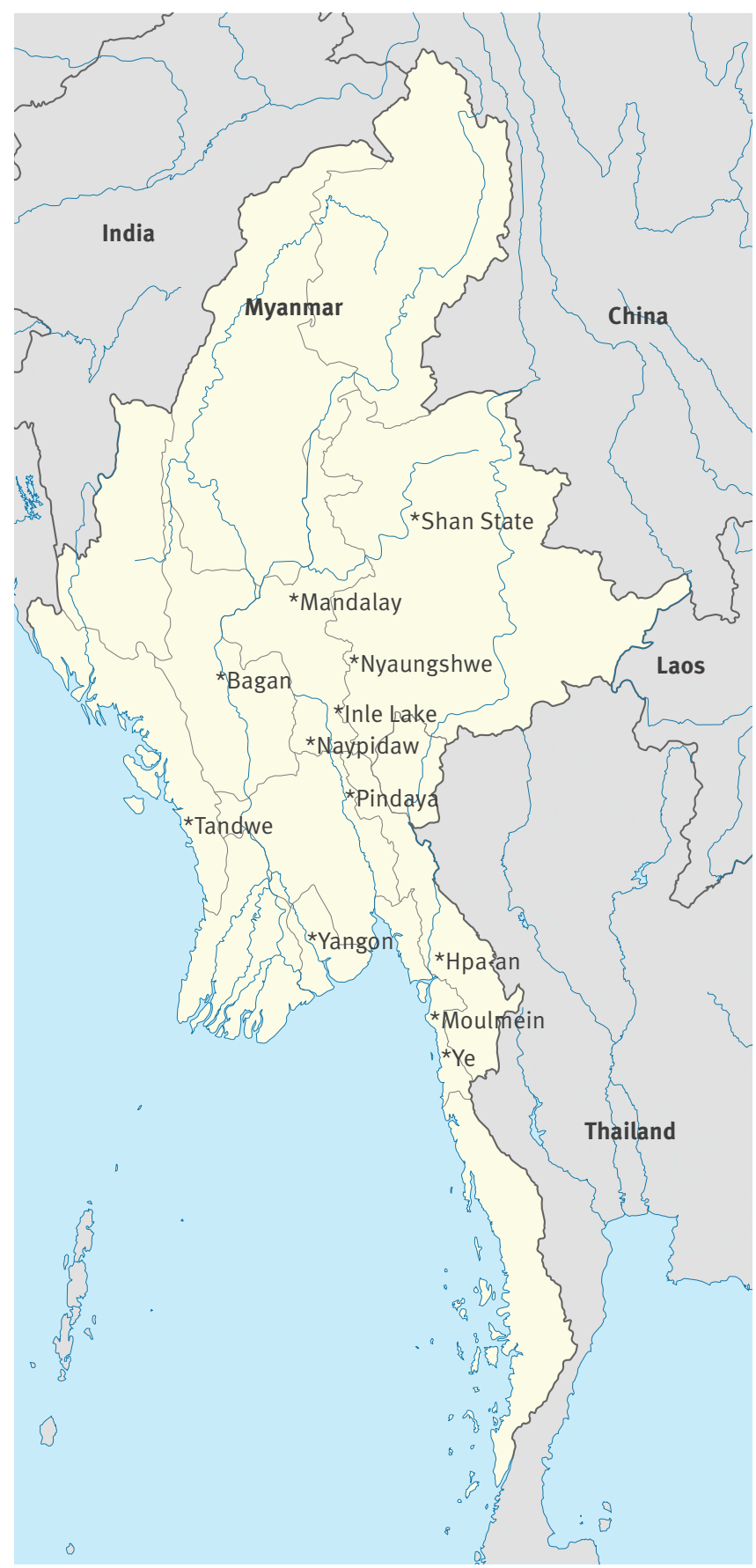

Asterisks represent the places where travellers in the current study were possibly exposed to chikungunya virus. Some travellers visited the same destinations.

Source: Map adapted from Wikimedia Commons, the free media repository: https://commons.wikimedia.org/wiki/File:Myanmar location map.svg
(WHO) Regional Office for Southeast Asia [4]. Such definitions were used in the current report. A possible case was a patient with acute onset of fever $338.5^{\circ} \mathrm{C}$ and severe arthralgia/arthritis not explained by other medical conditions. A probable case was a patient meeting both the previously mentioned clinical criteria and the following epidemiological criteria: residing or having visited epidemic areas, having reported transmission within 15 days prior to the onset of symptoms. A confirmed case had to meet one or more of the following laboratory criteria, irrespective of the clinical presentation: (i) virus isolation in cell culture or animal inoculations from acute phase sera, or (ii) presence of viral RNA in acute phase sera as demonstrated by RT-PCR, or (iii) presence of virus-specific IgM antibodies in single serum sample in acute or convalescent stage, or (iv) fourfold increase in virus-specific $\lg G$ antibody titre in samples collected at least 3 weeks apart.

For this study, cases were excluded if they were not in Myanmar at the likely time of exposure, which was inferred from their date of symptom onset and the typical incubation period (defined as 3 to 7 days) [5] or if the travellers had more than one potential travel destination exposure based on the incubation period.

\section{Description of cases}

Epidemiological and clinical details for each patient were collected from reporting sites.

The 18 cases reported in the current study had a median age of 51years (range: 19-68years) and 10 were male (Table 1). Among the overall cases, one had visited friends and relatives in Myanmar at the likely time of exposure, two were there on a business trip and three were expatriates. The rest of the cases, which represented the majority $(n=12)$, were tourists who had experienced a median length of stay of 13 days in Myanmar (range: 6-65 days).

The majority of cases were imported to Europe $(n=13)$ and Asia $(n=4)$, with one case in the Americas. Fewer than half (7/16) of travellers with available information, received pre-travel advice. Destinations visited in Myanmar are shown in the Figure.

Among the 18 cases, acute symptoms reported included fever $(n=18)$, arthralgia $(n=16)$ and rash $(n=14)$ (Table 2). A median of 9.5 days (range: $1-240$ days) elapsed between symptom onset and diagnosis. Most travellers $(n=13)$ were identified at reporting sites between August and October 2019. Seven cases were confirmed by PCR, including five who were also found IgM positive, and nine cases were confirmed by a positive IgM only; the remaining two patients had probable diagnoses based on a single IgG positive serology. No acute coinfections with other arboviruses were described in the 16 patients tested for additional pathogens. 


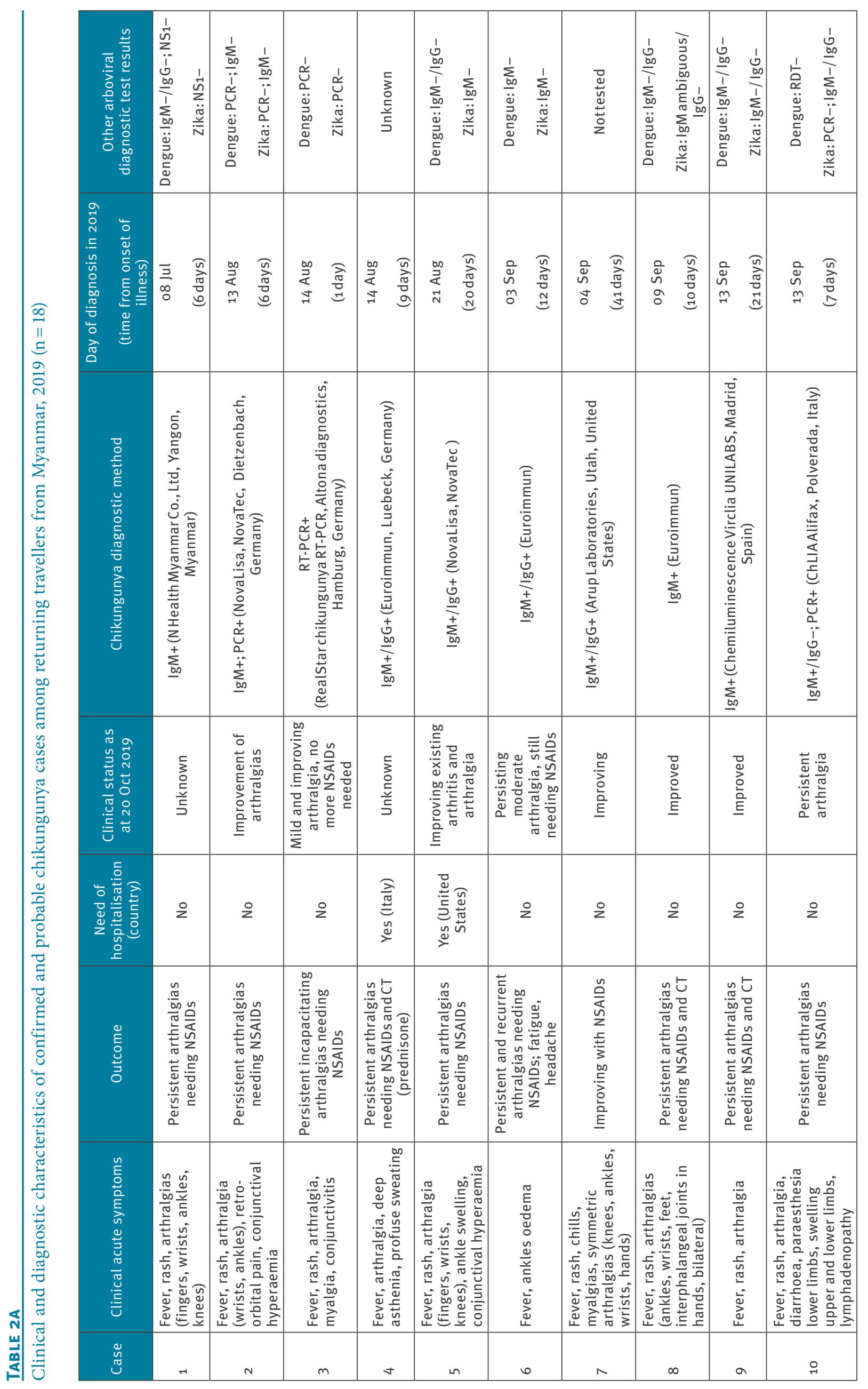




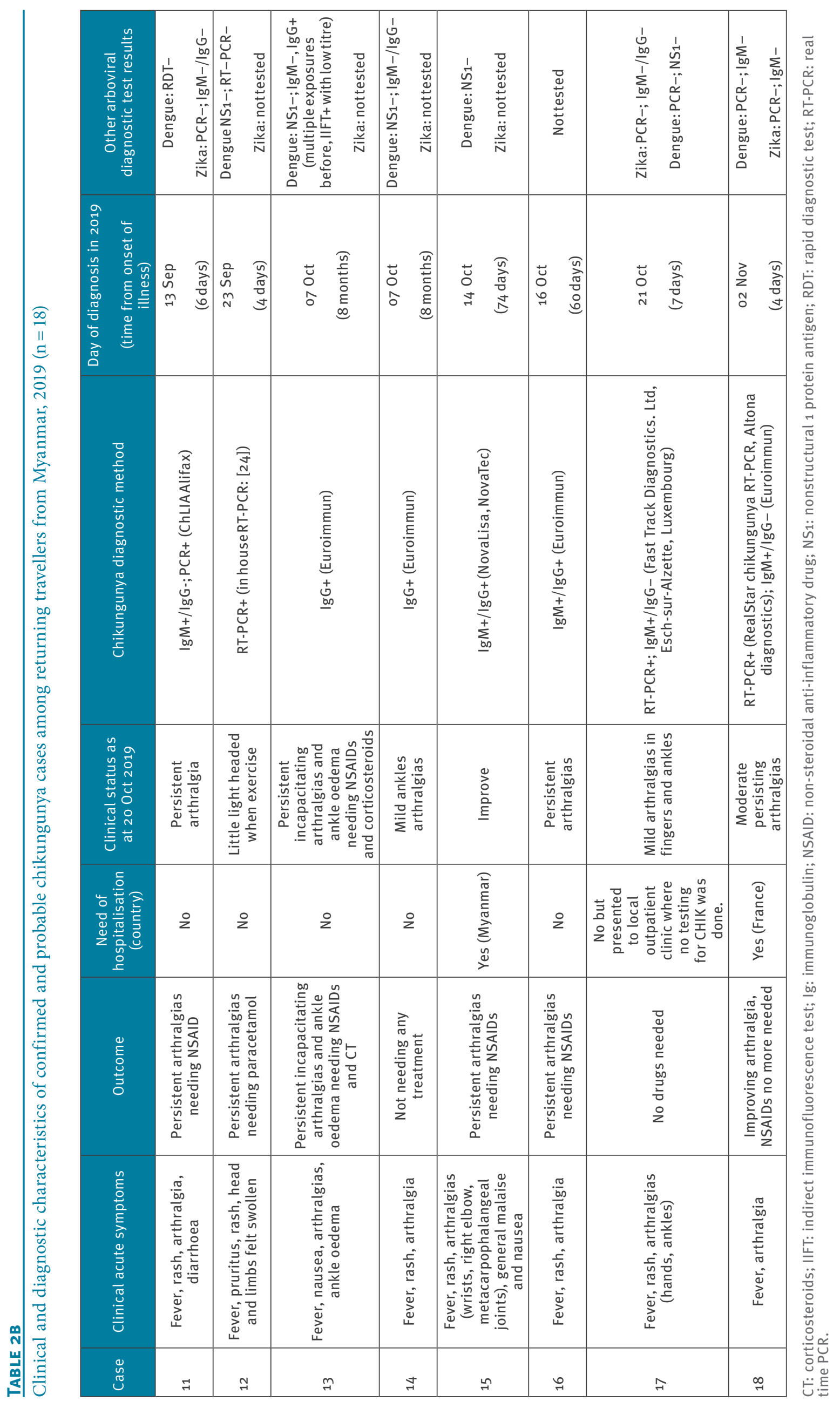


Four patients were hospitalised, and 15 needed nonsteroidal anti-inflammatory drugs; four had corticosteroids added to manage symptoms (Table 2). As at 20 October 2019, fourteen patients still had persistent symptoms, predominantly arthralgia.

\section{Discussion}

Chikungunya is often a mild self-limited illness, but severe and life-threatening complications have been described [6]. Persistent polyarthralgia can affect up to $40 \%$ of infected individuals and may last for months or years $[7,8]$. A high proportion of cases in our case series (14 of 18 ) had persistent sequelae (mainly arthralgia) that interfered with their daily life. Given the potential for long-term morbidity, the absence of a curative treatment or a preventive vaccine, detailed pre-travel counselling should focus on mosquito-bite prevention, particularly for those at high risk of incapacitating complications such as women older than 40 years, people with underlying rheumatic diseases, and professional athletes [9].

Considering the short duration of stay in different parts of Myanmar of many of the currently reported travellers, as well as the usual incubation period of chikungunya, the specific place where they were infected cannot be determined with certainty. Most patients in the case series acquired chikungunya from August to October, likely due to enhanced vector activity at the end or after the monsoon season, which occurs between May and August.

CHIKV has been detected in South and South East Asia since the 1950s [3], but its current epidemiology is poorly understood [10]. In Myanmar, CHIKV infection was first described in 1973 [11]. Since this time, the virus has caused outbreaks in 1998, 2006 and 2008 [3]. The number of reported cases subsequently declined until 2010, when local surveillance identified the last reported case [3]. Thereafter, from 2011 to 2018 no CHIKV cases were officially reported in the country, however a review of travellers who acquired chikungunya in Myanmar in the GeoSentinel database from 2000 to October 2019 revealed two cases in 2015 and 2016 , one probable and one confirmed.

In 2019, Myanmar's National Health Laboratory detected chikungunya cases again [1]. During the same year, other national surveillance systems also identified travellers who acquired chikungunya in Myanmar. For example, the Japanese National Institute of Infectious Diseases, which systematically tracks travellers, detected 28 imported cases of chikungunya from Myanmar to Japan [12]. The Italian Arboviriasis Surveillance System also detected four imported cases in Italy [13]. Our report highlights additional cases of exported CHIKV infection from Myanmar.

Little is known about factors contributing to the multiple detections of CHIKV infections in or from Myanmar in 2019. While aside from this year, no cases within the country had been officially observed since the end of 2010, the detection of exported cases in 2015 and 2016 could suggest that CHIKV might have continued to circulate in Myanmar after 2010. Myanmar's disease surveillance system includes a Central Epidemiology Unit (CEU) and several vertical control programmes [14]. Certain areas of the country are, however, difficult to access and there could have been underreporting due to limitations of surveillance capacity.

Myanmar has geographical and epidemiological characteristics that put it at risk for CHIKV epidemics: a highly susceptible population [15], a long border with two large neighbouring endemic countries (India and Thailand) with cross-border population movement for trade and travel purposes [16], and competent vectors (both Aedes aegypti and Ae. albopictus) [17]. According to the Thai Ministry of Public Health, CHIKV is currently circulating in Thailand with an increasing incidence: as at 30 October 2019, the country has reported 8,744 cases this year [18]. Coincidentally, GeoSentinel recently documented a rise in the number of travelassociated CHIKV infections from Thailand [19]. Without further epidemiological and phylogenetic evidence, it remains difficult to establish whether any links exist between cases in Thailand and those in Myanmar.

It should be noted that Myanmar is an increasingly popular tourist destination, with more than 3.5 million visitors in 2017 [20]. Hence, although we report more cases exported from Myanmar in 2019 than in previous years, a surge in tourism to this country may have led to an apparent increase of the number of exported cases. GeoSentinel data are moreover not populationbased so rates or risk estimates cannot be derived. Also, diagnostics depend on local site interpretation and reporting.

Imported CHIKV infection by viraemic travellers returning to their home countries raises the possibility of virus spread to these countries if competent vectors are present, mainly in hot seasons, as European Ae. albopictus is affected by seasonal temperature and undergoes a winter diapause [21]. There is also a potential risk of transmission by other routes, such as blood donation [22]. In Europe, some countries (Italy in 2007 and 2017, France in 2010, 2014 and 2017) have experienced autochthonous transmission of CHIKV through viraemic travellers [23]. Surveillance and early detection of both imported and autochthonous CHIKV infections is therefore relevant in areas with competent vectors, as well as close vector monitoring and rapid public health response.

This report of imported CHIKV infections reinforces the importance of travellers as sentinels of local outbreaks, particularly in settings with limited public health surveillance and reporting infrastructure. 
Acknowledgements

We would like to thank Dr. Chang-Kweng Lim in the Department of Virology, National Institute of Infectious Diseases of Japan, for his kind assistance with chikungunya diagnostics. We thank Pauline Perreau of the Department of Infectious Diseases and Tropical Medicine, CHU de Bordeaux, for her kind assistance with patient data extraction. We would finally like to thank Kristina M. Angelo of the CDC/DDID/NCEZID/DGMQ for her editorial assistance.

\section{Conflict of interest}

None declared.

\section{Authors' contributions}

Marta Díaz-Menendez, Elena Trigo Esteban, Mugen Ujiie, Guido Calleri, Camilla Rothe, Denis Malvy, Emanuele Nicastri, Alfred L. Bissinger, Marc Grandadam, Jonathan D. Alpern, Federico Gobbi, Alexandre Duvignaud, Takato Nakamoto, Spinello Antinori provided travel history as well as clinical and biological information on the travellers. Marta Díaz-Menendez, Elena Trigo Esteban and Davidson H. Hamer created the first draft of the manuscript and modified it according to the editorial team's comments. Emilie Javelle, Patricia Schlagenhauf and Davidson $\mathrm{H}$. Hamer reviewed and edited the manuscript. All authors provided input and reviewed the final version of the manuscript.

\section{References}

1. Myanmar Times. Chikungunya reappears after 10 years. [Accessed 20 Oct 2019]. Available from: https://www.mmtimes. com/news/chikungunya-reappears-after-10-years.html

2. Tun MM, Thant KZ, Inoue S, Nabeshima T, Aoki K, Kyaw AK, et al. Detection of east/central/south African genotype of chikungunya virus in Myanmar, 2010. Emerg Infect Dis. 2014;20(8):1378-81. https://doi.org/10.3201/eid2008.131431 PMID: 25062511

3. Wimalasiri-Yapa BMCR, Stassen L, Huang X, Hafner LM, Hu W, Devine GJ, et al. Chikungunya virus in Asia - Pacific: a systematic review. Emerg Microbes Infect. 2019;8(1):709. https://doi.org/10.1080/22221751.2018.1559708 PMID: 30866761

4. World Health Organization South-East Asia Regional Office (WHO SEARO). Proposed case definition of Chikungunya Fever (WHO, SEARO). New Delhi: WHO SEARO. [Accessed 19 Dec 2019]. Available from: http://origin.searo.who.int/entity/ emerging_diseases/topics/Def_Chikungunya_Fever.pdf

5. Silva JVJ Jr, Ludwig-Begall LF, Oliveira-Filho EF, Oliveira RAS, Durães-Carvalho R, Lopes TRR, et al. A scoping review of Chikungunya virus infection: epidemiology, clinical characteristics, viral co-circulation complications, and control. Acta Trop. 2018;188:213-24. https://doi.org/10.1016/j. actatropica.2018.09.003 PMID: 30195666

6. Economopoulou A, Dominguez M, Helynck B, Sissoko D, Wichmann O, Quenel P, et al. Atypical Chikungunya virus infections: clinical manifestations, mortality and risk factors for severe disease during the 2005-2006 outbreak on Réunion. Epidemiol Infect. 2009;137(4):534-41. https://doi.org/10.1017/ S0950268808001167 PMID: 18694529

7. Schwartz O, Albert ML. Biology and pathogenesis of chikungunya virus. Nat Rev Microbiol. 2010;8(7):491-500. https://doi.org/10.1038/nrmicro2368 PMID: 20551973

8. Consuegra-Rodríguez MP, Hidalgo-Zambrano DM, VásquezSerna H, Jimenez-Canizales CE, Parra-Valencia E, RodriguezMorales AJ. Post-chikungunya chronic inflammatory rheumatism: Follow-up of cases after 1 year of infection in Tolima, Colombia. Travel Med Infect Dis. 2018;21:62-8. https:// doi.org/10.1016/j.tmaid.2017.11.013 PMID: 29203304

9. van Aalst M, Nelen CM, Goorhuis A, Stijnis C, Grobusch MP. Long-term sequelae of chikungunya virus disease: A systematic review. Travel Med Infect Dis. 2017;15:8-22. https://doi.org/10.1016/j.tmaid.2017.01.004 PMID: 28163198

10. Pulmanausahakul R, Roytrakul S, Auewarakul P, Smith DR. Chikungunya in Southeast Asia: understanding the emergence and finding solutions. Int J Infect Dis. 2011;15(10):e671-6. https://doi.org/10.1016/j.ijid.2011.06.002 PMID: 21775183

11. Thaung U, Ming CK, Swe T, Thein S. Epidemiological features of dengue and chikungunya infections in Burma. Southeast Asian J Trop Med Public Health. 1975;6(2):276-83. PMID: 126493

12. National Institute of Infectious Diseases (NIID) Japan; Infectious Diseases Control Division (IDCD), Ministry of Health, Labor and Welfare (MHLW), Japan. IDWR (Infectious Diseases Weekly Report), week 42, as of 6 Oct 2019: NIID; 2019. [Accessed 29 Oct 2019]. Available from: https://wwwo.nih. go.jp/niid/idsc/idwr/IDWR2019/idwr2019-42.pdf

13. Sistema di Sorveglianza delle Arbovirosi Rapporto n.6, 2019. [Accessed 19 Dec 2019]. Available from: https://www. epicentro.iss.it/arbovirosi/pdf/Chik_2019.pdf

14. Latt NN, Myat Cho S, Htun NM, Myint MN, Aoki F, Reyer JA, et al. Yu Mon Saw. Healthcare in Myanmar. Nagoya J Med Sci. 2016;78(2):123-34. PMID: 27303099

15. Ngwe Tun MM, Inoue S, Thant KZ, Talemaitoga N, Aryati A, Dimaano EM, et al. Retrospective seroepidemiological study of chikungunya infection in South Asia, Southeast Asia and the Pacific region. Epidemiol Infect. 2016;144(11):2268-75. https:// doi.org/10.1017/S095026881600056X PMID: 27018566

16. Pulmanausahakul R, Roytrakul S, Auewarakul P, Smith DR. Chikungunya in Southeast Asia: understanding the emergence and finding solutions. Int J Infect Dis. 2011;15(10):e671-6. https://doi.org/10.1016/j.ijid.2011.06.002 PMID: 21775183

17. World Health Organization (WHO). Prevent Dengue \& Chikungunya, WHO Myanmar newsletter special; 9 September 2019. Available from: https://www.who.int/docs/defaultsource/searo/myanmar/prevent-dengue-and-chikungunya. pdf?sfvrsn=9b1b3069_o

18. Department of Disease Control. Weekly Disease Forecast No.234 Chikungunya (3-9 November 2019). Department of Disease Control, Ministry of Public Health. [Accessed 88 Jan 2020]. Available from: https://ddc.moph.go.th/uploads/files en/28420191219085018.pdf

19. Javelle E, Florescu S-A, Asgeirsson H, Jmor S, Eperon G, Leshem $E$, et al. Increased risk of chikungunya infection in travellers to Thailand during ongoing outbreak in tourist areas: cases imported to Europe and the Middle East, early 2019. Euro Surveill. 2019;24(10):1900146. https://doi.org/10.2807/15607917.ES.2019.24.10.1900146 PMID: 30862335

20. World Tourism Organization. Myanmar: Country-specific: Basic indicators (Compendium) 2013-2017 (11.2018). [Accessed 24 Oct 2019]. Available from: https://www.e-unwto.org/doi/ abs/10.5555/unwtotfb0104010020142018201909

21. Medlock JM, Avenell D, Barrass I, Leach S. Analysis of the potential for survival and seasonal activity of Aedes albopictus (Diptera: Culicidae) in the United Kingdom. J Vector Ecol. 2006;31(2):292-304. https://doi.org/10.3376/10811710(2006)31[292:AOTPFS]2.0.CO;2 PMID: 17249347

22. Appassakij H, Khuntikij P, Silpapojakul K, Promwong C, Rujirojindakul P, Suddeaugrai 0 , et al. Risk of chikungunya virus transmission associated with European travelers returning from southern Thailand (2008-2015). Transfusion. 2019;59(8):2612-21. https://doi.org/10.1111/trf.15401 PMID: 31228360

23. Díaz-Menéndez $M$, Crespillo-Andújar C. Literature review of mosquito-borne viral infections in non-tropical European Union territories: A cause of concern? Enferm Infecc Microbiol Clin. 2019;37(9):619-20. https://doi.org/10.1016/j.eimc.2018.12.002 PMID: 30594320

24. Pastorino B, Bessaud M, Grandadam M, Murri S, Tolou HJ, Peyrefitte CN. Development of a TaqMan RT-PCR assay without RNA extraction step for the detection and quantification of African Chikungunya viruses. J Virol Methods. 2005;124(12):65-71. https://doi.org/10.1016/j.jviromet.2004.11.002 PMID: 15664052

\section{License, supplementary material and copyright}

This is an open-access article distributed under the terms of the Creative Commons Attribution (CC BY 4.0) Licence. You may share and adapt the material, but must give appropriate credit to the source, provide a link to the licence and indicate if changes were made.

Any supplementary material referenced in the article can be found in the online version.

This article is copyright of the authors or their affiliated institutions, 2020. 